\title{
In-service training argumentation application for elementary school teachers: Pilot study ${ }^{1}$
}

\author{
Menşure Alkış Küçükaydın' ${ }^{1}$ Şafak Uluçınar Sağır² and İlker Kösterelioğlu \\ ${ }^{1}$ Amasya University Institute of Social Science , Amasya TURKEY \\ ${ }^{2}$ Amasya University Faculty of Education, Amasya TURKEY \\ For correspondence: mensurealkis@hotmail.com
}

\begin{abstract}
Science Course Curriculum was revised in Turkey in 2013 and some methods and strategies were suggested to be included such as argumentation. This study includes the evaluation of in-service training applied as pilot study for introducing argumentation to elementary school teachers. The study consists of applying needs analysis, preparing and applying programme and then evaluating the effectiveness of in-service training programme. After the application we made suggestions for main implementation according to the findings of pilot study.
\end{abstract}

Keywords: science curriculum, argumentation, in-service training, elementary school teacher

\section{Introduction}

The studies in the field of education are based on proper methods and approaches for effective teaching. According to results of the researches, some changes are made on the current program and innovations in curriculum. It is possible to show the revision of the Science Course Curriculum for Elementary Schools in 2013 as the latest innovations. The vision of new Science Course Curriculum is described as "To train all students as scientific literacy" (The Ministry of National Education, 2013, p.1). From this vision, some methods and strategies are adopted based on inquiry including argumentation. Argumentation can be described as "the relation between data and assertion by evaluating data and using reason" (Jimenez-Alexandre \& Erduran, 2008, p. 3971). According to Toulmin (1958) arguments consist of claims about a series of data. These assertions are evaluated and then whether they are accepted or refused. Dealing with the elements in an argumentation, Toulmin's argumentation model starts with a claim then including the data supporting that claim, and then reasons linking data and claim, the supports for enforcing the reasons, the limiters and finally ends with refusing in case of invalid claim (Erduran, Simon \& Osborne, 2004). Arguments can be organized as written or oral in this general pattern (Ryu \& Sandaval, 2013). That teachers and students understand different usage of an argument in science is an important issue for example; any argument can be used for different purposes in daily life or several disciplines as politics, history or religion. The figure below can be an example for us to explain these differences and evaluate the benefits of scientific arguments. According to Figure 1 the claim is a conjecture, conclusion, explanation or an answer to a research question (Sampson et al., 2010, p.221). Evidence which is one of the components of argument is the findings obtained by observations, measurements or other studies. The evidences can also be evaluated by one or two explanations or emphasizing the importance of them. But here it is important that evidences be accepted as scientific. So that empirical and theoretical criteria are emphasized in the figure. While empirical criteria emphasizes fit with accessible evidences of the claim, quality and predictive power of the evidence, theoretical criteria emphasizes sufficiency of claim, usefulness and consistency with other theories, rules or models (Horak et al., 2013). So argumentation can be described as intellectual and social process in which created arguments will be

${ }^{1}$ This study was presented in ERPA International Congresses on Educationheld on 4-7 June 2015 in Athence 
tested and evaluated. In argumentation model, students will try to prove their ideas with sentences supporting their thoughts against objections by using their prior knowledge.

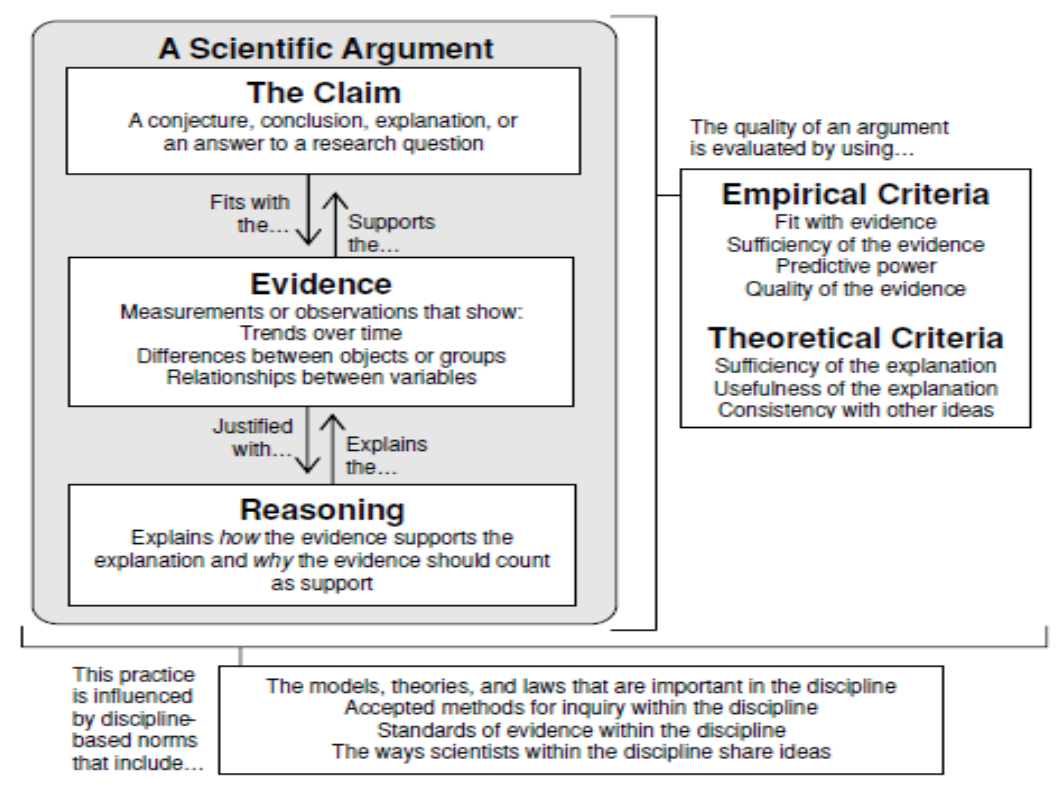

Figure 1.Criterias of a Scientific Argument

The evidence used for supporting assertions helps with improvement of critical ideas and higher order cognitive skills as the component of critical thinking. It is possible to join all these components under the title of scientific literacy.According to Norris and Phillips (2003) science literacy is divided into two categories. While one of them -derived information literacy- is included in former science curriculum, basic science literacy which eases science teaching through arguments is started to be used actively in recent years. The teacher who helps with basic science literacy and has an important role in science teaching is the key factor. The teacher does not only obtain basic concepts in the argumentation arrangements in the classroom environment but also s/he develops strategies for the effectiveness of argumentation applications (Xie\& So, 2012). According to the research, principally elements of an argument are clearly included in teaching procedure but the teachers cannot create well-structured argument in their classrooms. Eventually students don't have the opportunity to develop argumentation skills or make higher order reasoning (Özdem et al.,2011). For this reason, the teachers first have knowledge, skills and experience about argumentation and direct the applications effectively. At this point teachers need in-service training activities to introduce argumentation and provide opportunity to apply it.

After a certain training process the individuals who participate in business world may need in-service training for technological, social and economic reasons or for lack of information and application in his/her prior education. For this reason all education processes that the individuals have from the starting day of working until the retirement is called as in-service training (Kayabaş, 2008). In-service training can consist of summer school, correspondence courses, curriculum revision applications, cooperative learning and research, oriented reading, demonstration training, professional lessons, teacher meetings and integration courses for new teachers (Edmiston,1937). Service training activities in Turkey are conducted by Ministry of Education and goals, contents, targets and principles are organised according to In-Service Training Regulations. In Turkey especially in recent years Ministry of Education has started to work on improvements in the field of science teaching and that situation brings about teachers training through service training. But that improvements and innovation works organized only in specific regions because of the central organizations and probable handicaps at the stages of the programme are frequently criticised situations (Akar, 2007). Together with this the teachers mention some elements that prevent their professional developments as; handicaps in buying 
and reading professional publications, lack of motivation, lack of activities for professional development at schools, ignoring teachers' opinions while preparing service training programme, being unable to choose required service training courses, not considering the needs of service training, inexpert programme instructors, physical handicaps and expensive service training courses (Özer,2004).

However, the teachers need to renew themselves in professional work, personal contact, taking part in social work, trips, art galleries analysing themselves and choosing right interests in order to reach their educational goals (Allen, 1940). So service training courses are necessary for not only one way information transfer but also classroom environments where the teachers get mutual information exchange by talking about their own experiences. Therefore it is basis that teacher training itself be a dynamic process. An effective service training application should meet certain needs of the teachers. Same topics shouldn't be repeated and there should be cooperation between sharers. Pilot work is especially important to decide whether the new curriculum is effective or not (Ramatlapana, 2009). From that point, the aim of this study is to introduce argumentation which is one of recommended methods in 2013 Science Curriculum to primary school teachers and to find the shortcomings and difficulties by applying pilot study. Accordingly here are the research questions: "Is argumentation inservice training effective on the skills and knowledge of primary school teachers? What are the problems and difficulties during the pilot application?"

\section{Method}

This study is a pilot application to find out deficiencies before in-service training to introduce argumentation to primary school teachers. It was planned according to case study. At the first stage of study; we tried to find the service training needs of primary teachers for argumentation and applied semi-structured interview form. The questions prepared by the researchers for in-service training were first examined by two instructors working on service training area and one instructor on science teaching area to ensure content validity and put into final form with 7 questions in total. The final form was applied to 10 teachers in total who work in different locations and have different experiences by considering the situations that they work in cities, districts or towns by using maximum multi-sampling method. A service training program draft was designed according to the data obtained by application results. In this study sampling method was not applied but $3^{\text {th }}$ and $4^{\text {th }}$ grades class teachers participated voluntarily who work around Turhal district of Tokat. At the final section of study, question form was applied to 33 teachers attending to service training program voluntarily to determine shortcomings and advantages of service training program. Question form includes five questions and teachers were demanded to state their opinions about the benefits of this study and contributions of argumentation applications to their career and personal development.

Service training program included 2013 Science Curriculum, introduces argumentation and applying and evaluating argumentation implementations. In the study as a first step, revised science curriculum and changes were introduced and then model implementations were performed after giving theoretical information about argumentation. At the implementation stage, argumentation implementations were done by considering $3^{\text {th }}$ and $4^{\text {th }}$ grade acquisitions. First researcher provided training for argumentation and other specialist researchers carried out implementation process. During argumentation implementation process, teachers were asked to form a group of 4-5, choose acquisition and design argumentation activities and present them. Teachers chose their own groups. Each group had 15 minutes to present their argumentation activities. The argumentation activities prepared by teachers were criticized and evaluated by other participants. All implementation process including application of activities and criticizing took 170 minutes.

The data gained during the needs assessment process were written in chart and subjected to descriptive analysis by directly quoting the data results of participants. 21 participant teachers out of 
33 accepted to fill the question form. The percentage and frequency were calculated according to analysis of question form and descriptive analysis was applied by quoting the suggestions.

\section{Findings}

In this study, a service training activity was developed and applied to introduce argumentation and new curriculum to class teachers. The findings gathered using data collection tools were presented in two parts. The first section includes determining the situation and findings of needs assessment phase; the other section includes findings gathered during service training evaluation.

Findings of needs analysis phase

Semi structured interview form is prepared to determine the needs of class teachers for the reforms of revised 2013 science curriculum and along with the needs for service training program for accepted argumentation method. Here are findings of interview form applied to 10 teachers.

Table1. Findings of Interview Form

\begin{tabular}{|c|c|c|c|c|c|c|c|}
\hline Order & Sex & P.S. & A.N.P & M.T. & A.K. & S.S.T. & D.S.T. \\
\hline 1 & $\mathrm{M}$ & $\begin{array}{l}11-15 \\
\text { years }\end{array}$ & No & $\begin{array}{l}\text { Research , question- } \\
\text { answer, } \\
\text { brainstorming, } \\
\text { experimentation }\end{array}$ & No & No & Argumentation \\
\hline 2 & M & $\begin{array}{l}16-20 \\
\text { years }\end{array}$ & No & $\begin{array}{l}\text { Expression, question- } \\
\text { answer, drama }\end{array}$ & No & No & Experimentation \\
\hline 3 & $\mathrm{M}$ & $\begin{array}{l}16-20 \\
\text { years }\end{array}$ & Yes & $\begin{array}{l}\text { Question-answer, } \\
\text { problem solving }\end{array}$ & No & No & Argumentation \\
\hline 4 & $\mathrm{M}$ & $\begin{array}{l}11-15 \\
\text { years }\end{array}$ & No & $\begin{array}{l}\text { Observation, } \\
\text { experimentation }\end{array}$ & No & No & $\begin{array}{l}\text { Discovery } \\
\text { method }\end{array}$ \\
\hline 5 & $\mathrm{~F}$ & $\begin{array}{l}6-10 \\
\text { years }\end{array}$ & No & $\begin{array}{l}\text { Observation, } \\
\text { Expression, question- } \\
\text { answer, brainstorming }\end{array}$ & No & No & Argumentation \\
\hline 6 & $\mathrm{~F}$ & $\begin{array}{l}6-10 \\
\text { years }\end{array}$ & No & $\begin{array}{l}\text { Experimentation, } \\
\text { observation, question- } \\
\text { answer }\end{array}$ & No & No & Argumentation \\
\hline 7 & $\mathrm{M}$ & $\begin{array}{l}6-10 \\
\text { years }\end{array}$ & Yes & $\begin{array}{l}\text { Expression, question- } \\
\text { answer, } \\
\text { experimentation. }\end{array}$ & No & No & Argumentation \\
\hline 8 & $\mathrm{~F}$ & $\begin{array}{l}6-10 \\
\text { years }\end{array}$ & Yes & $\begin{array}{l}\text { Expression,question- } \\
\text { answer, }\end{array}$ & No & No & Experimentation \\
\hline 9 & $\mathrm{~F}$ & $1-5$ years & Yes & $\begin{array}{l}\text { experimentation, } \\
\text { observation }\end{array}$ & No & No & Drama \\
\hline 10 & $\mathrm{M}$ & $\begin{array}{l}20 \text { years } \\
\text { and over }\end{array}$ & No & $\begin{array}{l}\text { Expression, question- } \\
\text { answer, }\end{array}$ & No & No & $\begin{array}{l}\text { Argumentation, } \\
\text { drama, } \\
\text { experimentation }\end{array}$ \\
\hline
\end{tabular}

P.S: professional seniority

A.N.P.: awareness of new curriculum

M.T.: methods and techniques used in the lesson and techniques
A.K.:argumentation knowledge

S.S.T: state of having service training

D.S.T. demanded service training methods

According to Table 1, 6 male participant teachers have higher professional seniority than 4 female teachers. In general, none of the participants have information about argumentation and they have never participated any in-service training program up that time. The majority of participants during 
the interview said; "This is the first time we have heard about argumentation and we want to take part in service training activity". The $9^{\text {th }}$ female participant said: "I heard about argumentation while I was studying KPSS (public personnel selection exam) but I didn't have information about it" and seventh male participant said: "I haven't heard this term before. As far as I understood it aims to educate students to make scientific discussion but I am sure it will be difficult because of their background". The teachers who are not aware of argumentation said they didn't know anything about the changes in the curriculum because they didn't participate any in service training program. While first male participant said: "I was surprised when I saw the new science book, nobody mentioned about the curriculum change", the $9^{\text {th }}$ female participant said:"I do not know how to give lecture, it has been 2,5 months since the school started but I have already finished the book". The participants emphasized that the new program should be introduced. When we look at the methods used by participants in their lessons, we see that they especially focus on narration and question-answer method.

\section{Findings Gathered from Service Training Evaluation Interview Form}

After service training activity, we handed out the form including five questions to participants and asked their opinions and suggestions about the activity. The percent and frequency of answers are shown below in the table but second unanswered questions are not included in the table.

Table 2. The Proportions of Percent and Frequency of Activity Evaluation Results

\begin{tabular}{lcc}
\hline \multicolumn{1}{c}{ Questions / $(\mathrm{n}=21)$} & $\mathrm{f}$ & $\%$ \\
\hline $\begin{array}{l}\text { Do you think you had enough time to achieve activity aims? } \\
\text { Were there enough examples about argumentation and do you think }\end{array}$ & 10 & 48 \\
the applications were sufficient? & 8 & 38 \\
$\begin{array}{l}\text { Can you use the information you got about argumentation in your } \\
\text { llassroom? }\end{array}$ & 19 & 90 \\
$\begin{array}{l}\text { Did you realize any deficiencies or problems in your service training } \\
\text { activity }\end{array}$ & 1 & 5 \\
$\begin{array}{l}\text { Do you think this service training activity will contribute to your } \\
\text { personal and professional development? }\end{array}$ & 17 \\
\hline
\end{tabular}

When we look at percent and frequency of answers of class teachers to activity evaluation question forms, $48 \%$ participants thought that activity time was enough on the other hand $52 \%$ were not satisfied with the timing. About this a participant said: "We could have more time. It was difficult to participate in this activity after school". Just $38 \%$ participants said that the examples about argumentation were enough. Some answers about this issue are as follows: "There can be more examples. We can practice course acquisitions for argumentation together", "There should be more explanatory examples. Applied videos are useful, you should use more videos". According to findings, $90 \%$ participants wanted to apply argumentation activities in their classes but just $5 \%$ think there were problems in the activity. At this point, just one of the participants said:"The activity can be longer and more effective". 85\% participants thought that this service training activity was certainly an opportunity for their professional development, the other $15 \%$ thought that the activity was partly useful. The participants said: "It was certainly useful. It changed my point of view", "Of course, I am planning to mention on this topic more frequently". "Yes. I got new information", "It was helpful. I will search it on the internet". The participants answered the question 'what are the benefits and shortcomings of argumentation?', they answered it as "Students have chance to work in groups, they can easily express their opinions", "We will have timing problems, course acquisitions won't be completed on time", "Students will be able to exchange opinions", "We will have difficulties in controlling the class", "It takes much time, it is not appropriate for all topics, I can use it for certain topics", "Science lesson will be more enjoyable. There will be timing problems". 


\section{Discussion and Conclusion}

At the end of the in-service training activity in which revised science course curriculum and argumentation applications were introduced considering the answers of the participant teachers, we conclude that teachers were satisfied with the activity. The biggest problem they encountered during the activity was based on inadequate time and participating the activity after school. At this point we were able to do the activity only after school because of the permissions from authorities and teachers were not satisfied with it. The participant class teachers emphasized that this activity should be continued and repeated in certain intervals. As Arıbaş and Göktaş (2014) indicated in their studies this situation is about the persistence of service training activities. Additionally, participants wanted to prepare argumentation activities for all lesson acquisitions together with the practitioner but as it needs long time study participants should be introduced the method in a way that they can prepare their own activities. It is stated that the study will be very useful for personal and professional development. This proportion can be seen in similar research results (Uzal et al., 2010; Önen et al., 2010; Arıbaş \&Göktaş, 2014; Karaca, 2010). Another result of the research is that \%90 participants decided to use argumentation in their classrooms. But they think that they will have problems in completing the curriculum so they are planning to use argumentation for critical acquisitions for each lesson.

Here are the suggestions based on the findings of the research applied for finding out what is needed for main application by doing pilot study.

$\checkmark \quad$ First of all, the activities should be applied in June and September during teachers' seminar period by getting necessary legal approvals,

$\checkmark \quad$ In this period activity time should be prolonged and sample applications and videos should be shown for more acquisitions,

$\checkmark$ At the end of the activity it should be controlled whether volunteer teachers use argumentation in their classrooms or not by applying follow-up studies,

$\checkmark$ During the argumentation applications with the volunteer teachers, they should be guided to prepare their own activities actively by making groups,

$\checkmark \quad$ The argumentation activities prepared by teachers should be gathered in a single form and a pool of activities can be provided for the participant teachers to use them later on.

\section{Acknowledgements}

This research was supported by Amasya University SEB BAP 14-032 with project, headed by Associate Professor Şafak Uluçınar Sağır.

\section{References}

Akar, E.Ö. (2007). In-service training needs of biology teachers and observed local differences .Science and Education, 32 (143), 68-79.

Allen, C.H. (1940). In-service training of teachers.Review of Educational Research,10(3), 210-215.

Arıbaş,S. \&Göktaş,Ö. (2014). Secondary school math teachers' views on necessities of in-service trainings for alternatives measurement and evaluation.Adıyaman Üniversitesi Sosyal Bilimler Enstitüsü Dergisi, 7 (16),17-42.

Edmiston, R.W. (1937). In-service training of teachers.Review of Educational Research.7 (3), 273-275.

Erduran, S., Simon, S. \& Osborne, J. (2004).Tapping into argumentation: Developments in the application of Toulmin's argument pattern for studying science discourse.Science Education,88, 915-933.

Horak, J., Cooke A., Rubin W., Bannigan, A. \& America, A. (2013). Scientific argumentation in biology 30 classroom activities. In Reinburg, C. (Ed.),What is scientific argumentation? National Science Teachers Association Press.

Jimenez-Alexandre, M.P.\&Erduran, S. (2008). Argumentation in science education: An overview.In S. Erduran\& M.P. JimenezAlexandre (Eds.), Argumentation in Science Education: Perspectives from Classroom-Based Research. Dordrecht: Springer.

Karaca,A. (2010). Primary school teachers' opinions about in servicetraining programs(Mudurnu case).Unpublished Master Thesis, Abant İzzet Baysal Üniversitesi, Bolu. 
Kayabaş, Y. (2008). The importance of in-service training for teachers and its principles.TSA,12(2), 11-32.

Ministry of National Education.(2013). Elementary science curriculum of institutions. TalimTerbiye Kurulu Başkanlığı, Ankara: Turkey.

Norris, S.P. \& Phillips, L.M.(2003). How literacy in its fundamental sense is central to scientific literacy. Science Education, 87(2), 224-240.

Önen, F., Mertoğlu, H., Saka, M. \&Gürdal, A.(2010). The effects of in service training on teachers' knowledge about projectbased learning and competencies for conducting projects: Öpyep case.Ahi Evran Üniversitesi Ĕ̆itim Fakültesi Dergisi, 11(1), 137-158.

Özdem, Y., Ertepınar, H., Çakıroğlu J. \&Erduran, S. (2013). The nature of pre-service science teachers' argumentation in inquiry oriented laboratory context.International Journal of Science Education, 35(15), 2559-2586.

Özer, B. (2004). In-Service Training of Teachers in Turkey at the Beginning of the 2000s. Journal of In-Service Education, 30(1), 89100.

Ramatlapana, K.A. (2009). Provision of in-service training of mathematics and science teachers in Botswana: Teachers' perspectives.Journal of Mathematics Teacher Education, 12,153-159.

Ryu, S. \& Sandoval, W. (2012).Improvements to elementary children's epistemic understanding from sustained argumentation.Science Education, 96(3), 488-526.

Sampson, V., Grooms, J. \& Walker, J.P. (2010). Argument-driven inquiry as a way to help students learn how to participate in scientific argumentation and craft written arguments: An exploratory study.Science Education, 95(2), 217-257.

Toulmin, S. E. (1958).The Uses of Argument, Cambridge University Press, Cambridge.

Uzal, G., Erdem, A., Önen, F. \&Gürdal, A. (2010).The evaluation of teachers' opinions about hands-on science experiments and the performed in-service training.Necatibey Faculty of Education Electronic Journal of Science and Mathematics Education, 4(1), 64-84.

Xie, Q. \& So, W.W.M.(2012). Understanding and practice of argumentation: A pilot study with mainland Chinese pre-service teachers in secondary science classrooms.Asia-Pacific Forum on Science Learning and Teaching, 13(2), 1-20. 